\title{
Patient Satisfaction as a Nursing Care Quality Indicator in the ICU
}

${ }^{1,2}$ Adriano Friganović

2 Sonja Kalauz

1 Maida Redžić

2 Boris Ilić

2 Irena Kovačević

3 Sandro Vidmanić

1 University Hospital Centre Zagreb

2 University of Applied Health Sciences in Zagreb

${ }^{3}$ University Hospital Centre Rijeka

Article received: 31.10.2017.

Article accepted: 16.01.2018.

Author for correspondence:

Adriano Friganović

University Hospital Centre Zagreb

University of Applied Health Sciences in Zagreb

email: adriano@hdmsarist.hr

DOI: $10.24141 / 2 / 2 / 1 / 1$

Keywords: quality indicators, patient satisfaction, nurse, nursing care

\section{Abstract}

Aim. Patient satisfaction with provided nursing care is an important quality indicator. This study aimed to determine the factors and the level of patient satisfaction in the ICU. The aim was also to determine and compare satisfaction levels among patients with regard to their level of education and the length of their stay in the ICU.

Hypotheses. Hypothesis 1: The level of satisfaction with provided nursing care will be significantly lower among patients who have a higher level of education. Hypothesis 2: Patients will show a higher level of satisfaction with the provided nursing care when the length of their stay in the ICU is shorter.

Methods. A cross-sectional study was conducted on 150 patients treated in intensive care units at the University Hospital Centre Zagreb during a period of 6 months. The survey contained a total of 24 closedended questions. The study hypotheses were tested using the chi-squared test.

Results. The study confirmed the starting hypothesis 1 , stating that patients with a higher level of education have lower satisfaction levels than patients with a lower level of education. The hypothesis 2, which assumed that patients with shorter hospital stays, defined in our survey as a stay of no more than five days, were more satisfied with conditions in the ICU than those who stayed longer than five days, has been dismissed.

Conclusion. Patients with a higher education level have higher expectations from health care providers which results in lower satisfaction levels with the provided nursing care. The longer patients stay in hospital wards, the higher the probability of finding potential reasons for dissatisfaction. 


\section{Introduction}

New trends in healthcare economics cause greater need for better regulation and the introduction of a quality control system in the provision of health care. The continuing progress in medicine and other similar fields contribute to a growing application of quality standards in healthcare. The quality of treatment and nursing care provided to the patient also changed significantly through history. Different principles of quality management were being developed that were later adapted to specific features of health care. The aim of healthcare policies is to preserve and improve health and increase life expectancy and quality of life for the general population and individuals. Patients in the ICUs (intensive care units) have a broad spectrum of different health conditions and consequent complications so that their treatment is very complicated and expensive. (1). Environments such as the ICUs are extremely stressful, especially because of higher expectations placed upon health care providers to provide safe and quality health care (1). Complicated and expensive treatments put an even higher strain on healthcare staff, especially nurses, whose staffing levels are not in line with the recommended standards (2). Within healthcare there is a need for better indicators of quality that would enable head nurses to compare health care standards and introduce strategies for quality improvement (3). Health care quality indicators are a uniform measure made up of two or more quality measures that enable simple evaluation and comparison (4). The measurement of quality is a key factor in planning, organization and evaluation of performed activities (5) but in order to carry out these measurements, quality indicators are needed (5). In light of extensive globalisation, nursing is faced with the problem of providing quality nursing care through furthering scientific and technological knowledge (6). Strategies enabling the evaluation of provided health services, including nursing care, depend on the creation of good quality indicators aimed at efficiency and effectiveness (5). Quality indicators in the healthcare system are metric units whose purpose it is to supervise and evaluate the quality of the provided service - in this case health care. Professional practice in health facilities influences the quality and safety of nursing care provided to the patient (7). International literature gives consistent recom- mendations, especially to health facilities, regarding the work environment and its influence on nurses, i.e. the safety of the provision of nursing care $(8,9)$. Many other studies point out that patient safety and nursing care quality improve in work environments where professional practice is promoted which helps to foster a safe climate and reduce the incidence of adverse events $(10,11,12,13)$. The work environment in healthcare organizations is a determining factor in the provision of safe and good quality care (7). A number of international studies confirmed the importance of the adaptation of staffing levels and proved that a balance in workload and human resource planning guarantee patient safety and the quality of provided nursing care $(14,15,16,17,18,19)$. A lack of planning results in an inadequate distribution of workload and consequently a lack of nurses. The nurse is not capable of fulfilling all of the patient's needs which is a great leadership challenge. It is a known fact that larger patient numbers distributed to an insufficient number of nurses are linked to adverse events and decreased patient satisfaction (20). Quality indicators are a strong instrument that helps head nurses to prove how relevant adequate nurse staffing is to the provision of nursing care in health facilities (21). Patient satisfaction has become a priority in all healthcare systems and health facilities, and as such is an extremely important indicator of provided health care (22). Literature review has shown that there is little research in the Republic of Croatia has been done on the sources of dissatisfaction, especially in the area of nursing care in hospital institutions. This study has the following aims:

1. To determine the sources and the level of patient dissatisfaction with their stay in the ICU.

2. To determine and compare (dis)satisfaction levels among patients with different levels of education.

3. To determine and compare satisfaction levels among patients with regard to the length of their stay in the ICU.

The aim of the study was to prove the following hypotheses:

Hypothesis 1: The level of satisfaction with provided nursing care will be significantly lower among patients with a higher level of education.

Hypothesis 2: Patients will show a higher level of satisfaction with the provided nursing care when the length of their stay in the ICU is shorter. 


\section{Methods}

A cross-sectional study has been done in order to determine the main sources of satisfaction among patients staying in the ICUs after general surgery, cardiac surgery and urological surgery procedures. The survey was conducted among 150 patients staying in the ICUs of the University Hospital Centre Zagreb between June and December of 2015.

The survey contained a total of 24 closed-ended questions. Six questions were intended to identify the study respondents' characteristics (sex, age, level of education, type of admission, length of stay and type of surgical procedure). The other 18 questions (indicators) were meant to provide a detailed study of the elements of patient satisfaction levels. For that purpose a balanced five-level Likert scale was used to measure attitudes. When using an odd number of levels, the central value stands for a neutral attitude meaning that the respondent is neither satisfied nor dissatisfied with the offered choice. On each side of the central value there is an equal number of levels of agreement (very satisfied and satisfied) and levels of disagreement (very dissatisfied and dissatisfied). Thus a very sensitive measuring instrument has been constructed offering to every respondent a broad range of elements and the possibility to gauge their satisfaction or dissatisfaction levels with regard to the provided nursing care, information about patients' rights, about catheters, length of stay and postoperative care, ways of communicating with the patients' families, visiting hours, peace and quiet in the hospital ward, personal hygiene as well as nutritional and even religious needs. In short, the purpose of the survey was to provide answers on patient satisfaction with regard to the nurses' rapport with them on the basis of five questions/ indicators; five questions related to the levels of information provided about postoperative care, while four of the questions referred to the involvement of patients in nursing care, i.e. therapy and pain treatment. The measuring instrument had been subdivided into four sub-scales covering the four areas of care: nursing care, nurse rapport, postoperative care and pain treatment.

\section{Ethical principles}

The Ethics Committee of the University Hospital Centre Zagreb has approved this study. Patients freely agreed to participate in the study and filled in the questionnaires correctly. Owing to hospital regulations the respondents had to sign a consent form. During this study the principles of the Declaration of Helsinki were adhered to.

\section{Statistics}

For data input and processing the SPSS software for statistical data processing version 16 was used. The software was used to create summary tables containing frequencies, percentages, means, standard deviations and crosstabs, as well as to perform the chisquared test ( $x^{2}$-test) for testing the study hypotheses.

\section{Results}

The first 6 questions were used to collect demographic data, displayed in Table 1.

\begin{tabular}{|ccc|}
\hline $\begin{array}{c}\text { Table 1. Demographic characteristics of the } \\
\text { respondents }\end{array}$ & f & $\%$ \\
\hline Sex & 97 & 64.7 \\
\hline Male & 53 & 35.3 \\
\hline Female & & \\
\hline Age & 9 & 6.0 \\
\hline $36-35$ & 9 & 6.0 \\
\hline $46-55$ & 26 & 17.3 \\
\hline $56-65$ & 46 & 30.7 \\
\hline >65 & 60 & 40.0 \\
\hline Education level & & \\
\hline Primary & 22 & 14.7 \\
\hline Secondary & 88 & 58.7 \\
\hline Post-secondary vocational & 14 & 9.3 \\
\hline Tertiary & 26 & 17.3 \\
\hline Type of surgical procedure & & \\
\hline Cardiac surgery & 48 & 32.0 \\
\hline General surgery & 53 & 35.3 \\
\hline Urological surgery & 49 & 32.7 \\
\hline Length of stay in the Icu & & \\
\hline Up to 5 days & 112 & 74.7 \\
\hline 6 to 10 days & 31 & 20.7 \\
\hline More than 10 days & 7 & 4.7 \\
\hline Elective & & \\
\hline Emergency & 124 & 82.7 \\
\hline Type ofient admission & 26 & 17.3 \\
\hline
\end{tabular}


The survey (in the annex) consisted of 18 questions on possible sources of patient satisfaction with their stay in the ICUs. The results are shown in table 2.

The results of the survey showed that $17.3 \%$ of the respondents marked none of the offered sources of dissatisfaction with their stay in the ICU. Among the other $83.7 \%$ a majority showed dissatisfaction with just one segment of their stay in the ICU. They accounted for $12.7 \%$ of all the respondents, and $15.3 \%$ of the respondents who expressed at least one grievance. Following the same reasoning in displaying results, two reasons for dissatisfaction were expressed by $9.3 \%$, i.e. $11.3 \%$ of the respondents, three reasons by $7.3 \%$, i.e. $8.9 \%$, four by $10.7 / 12.9 \%$, five by $10.0 / 12.1 \%$, six by $8.7 / 10.5 \%$, seven by $5.3 / 6.5 \%$, and eight by $4.0 / 4.8 \%$ of the respondents. Nine or more sources of dissatisfaction were pointed out by $14.7 \%$, i.e. by $17.7 \%$ of those surveyed among the group of respondents who expressed at least one grievance. Based on the presented data it is not possible to reach a valid conclusion, nor even to get an approximate proportion of respondents with prevailing dissatisfaction, i.e. the proportion of those who, despite some complaints, are nevertheless basically satisfied with their stay in the ICU. Therefore, the negative and positive answers were added up and their average proportions in every question calculated, in order to form a basis on which final average indicators of respondent satisfaction or dissatisfaction could be obtained. The obtained average values suggest that among respondents there are almost 2.5 times more answers with a positive attitude, i.e. expressions of satisfaction, than there is dissatisfaction regarding their stay in the ICUs (Figure 1 ).

Tables 3, 4 and Figures 2, 3 show the respondents' answers to all 18 questions designed as a 5 level Likert item for the expression of satisfaction and dissatisfaction as well as a dichotomous division after adding up the positive and negative levels of the Likert scale, along with the mean and the standard deviation.

\begin{tabular}{|ccc|}
\hline $\begin{array}{c}\text { Number of stated reasons for } \\
\text { dissatisfaction }\end{array}$ & $\begin{array}{c}\text { Percentage } \\
\text { of } \begin{array}{c}\text { all respondents } \\
(\mathbf{N}=\mathbf{1 5 0})\end{array}\end{array}$ & $\begin{array}{c}\text { Percentage of the respondent } \\
\text { group that stated at least } \mathbf{1} \text { reason } \\
\text { for dissatisfaction (N=124) }\end{array}$ \\
\hline None & 17.3 & - \\
\hline 2 & 12.7 & 15.3 \\
\hline 3 & 9.3 & 11.3 \\
\hline 4 & 7.3 & 8.9 \\
\hline 5 & 10.7 & 12.9 \\
\hline 6 & 10.0 & 12.1 \\
\hline 7 & 8.7 & 10.5 \\
\hline 8 & 5.3 & 6.5 \\
\hline 9 & 4.0 & 4.8 \\
\hline 10 & 3.3 & 4.0 \\
\hline 11 & 2.7 & 3.2 \\
\hline 12 & 1.3 & 1.6 \\
\hline 13 & - & - \\
\hline 14 & 2.0 & 2.4 \\
\hline 15 & 1.3 & 1.6 \\
\hline 16 & 0.7 & 0.8 \\
\hline 17 & 2.0 & 2.4 \\
\hline 18 & 1.3 & 1.6 \\
\hline
\end{tabular}




\section{Average proportion of satisfaction and dissatisfaction statements by patients in the ICU}

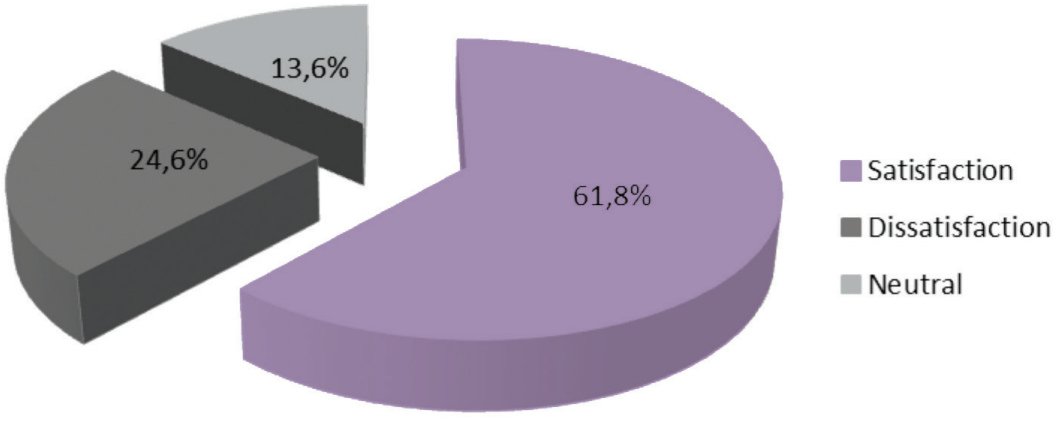

Figure 1. Average proportion of satisfaction and dissatisfaction statements by patients in the ICU

\section{Table 3. Percentage of respondent answers according to levels of dissatisfaction} with the stay in the ICU

\section{Questions}

1. Are you satisfied with the nurses' approach upon taking over their shift?

2. Are you satisfied with the time nurses spent talking with you?

3. Are you satisfied with the level of privacy during personal care?

4. Are you satisfied with the time the nurse spends on your care during their shift?

5. Are you satisfied with the peace and quiet during your stay in the ICU?

6. Are you satisfied with how the nurse is paying attention to your usual routines?

7. Are you satisfied with the attention paid to your nutritional habits?

8. Are you satisfied with the possibility to practice your religious needs?

9. Have you been informed about the course of postoperative care?

10. Have you been informed about your rights as a patient?

11. Are you satisfied with how your family was informed about your postoperative state and visiting hours?

12. Are you satisfied with the visiting hours during your stay at the ICU?

13. Are you satisfied with the information provided about catheters that were placed because of the surgical procedure?

14. Have you been informed about the average length of stay in the ICU?

15 . Have you been informed about ways of pain treatment in postoperative care?

16. Were you asked questions about your tolerance to pain?

17. Did you get adequate pain treatment upon request?

18. Are you satisfied with the pain treatment in the ICU?

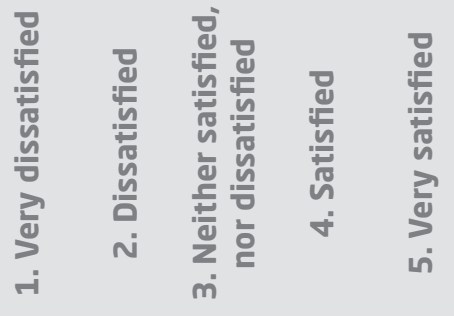

$\begin{array}{lllll}8.0 & 17.3 & 2.7 & 22.0 & 50.0\end{array}$

$\begin{array}{lllll}10.0 & 19.3 & 6.0 & 19.3 & 45.3\end{array}$

$\begin{array}{lllll}8.0 & 17.3 & 8.7 & 19.3 & 46.7\end{array}$

$\begin{array}{lllll}9.3 & 16.7 & 5.3 & 20.0 & 48.7\end{array}$

$\begin{array}{lllll}8.7 & 20.7 & 10.7 & 16.0 & 44.0\end{array}$

$\begin{array}{lllll}8.7 & 9.3 & 18.0 & 16.7 & 47.3\end{array}$

$\begin{array}{lllll}6.0 & 10.0 & 19.3 & 18.0 & 46.7\end{array}$

$\begin{array}{lllll}1.3 & 4.0 & 19.3 & 12.7 & 62.7\end{array}$

$\begin{array}{lllll}12.7 & 14.0 & 24.0 & 26.0 & 23.3\end{array}$

$\begin{array}{lllll}5.3 & 11.3 & 19.3 & 28.0 & 36.0\end{array}$

$\begin{array}{lllll}2.0 & 3.3 & 6.7 & 23.3 & 64.7\end{array}$

$\begin{array}{lllll}6.7 & 12.0 & 18.0 & 28.7 & 34.7\end{array}$

$\begin{array}{lllll}16.7 & 24.0 & 12.7 & 20.0 & 26.7\end{array}$

$\begin{array}{lllll}6.7 & 12.7 & 15.3 & 16.0 & 49.3\end{array}$

$\begin{array}{lllll}10.7 & 29.3 & 18.0 & 34.7 & 7.3\end{array}$

$\begin{array}{lllll}12.7 & 28.0 & 24.0 & 33.3 & 2.0\end{array}$

$\begin{array}{lllll}11.3 & 20.7 & 20.0 & 44.0 & 4.0\end{array}$

$\begin{array}{lllll}10.7 & 22.0 & 12.0 & 44.7 & 10.7\end{array}$ 


\section{Table 4. Percentage of respondent answers according to satisfaction or dissatisfaction} expression statements with the stay in the ICU

Questions

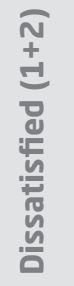

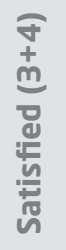

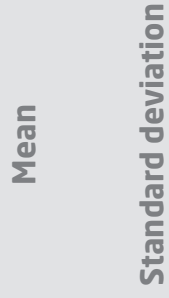

1. Are you satisfied with the nurses' approach upon taking over their shift?

2. Are you satisfied with the time nurses spent talking with you?

25.3

72.0

3.89

1.393

3. Are you satisfied with the level of privacy during personal care?

4. Are you satisfied with the time the nurse spends on your care during their shift?

5. Are you satisfied with the peace and quiet during your stay in the ICU?

6. Are you satisfied with how the nurse is paying attention to your usual routines?

7. Are you satisfied with the attention paid to your nutritional habits?

8. Are you satisfied with the possibility to practice your religious needs?

9. Have you been informed about the course of postoperative care?

10. Have you been informed about your rights as a patient?

29.3

64.7

3.71

1.454

25.3

66.0

3.79

1.392

26.0

68.7

3.82

1.424

29.3

60.0

3.66

1.432

18.0

64.0

3.85

1.340

16.0

64.7

3.89

1.265

5.4

75.3

4.31

1.004

26.7

49.3

3.33

1.319

16.7

64.0

3.78

1.203

11. Are you satisfied with how your family was informed about your postoperative state and visiting hours?

12. Are you satisfied with the visiting hours during your stay at the ICU?

13. Are you satisfied with the information provided about catheters that were placed because of the surgical procedure?

14. Have you been informed about the average length of stay in the ICU?

15. Have you been informed about ways of pain treatment in postoperative care?

16. Were you asked questions about your tolerance to pain?

17. Did you get adequate pain treatment upon request?

18. Are you satisfied with the pain treatment in the ICU?

Total average value: $\begin{array}{llll}5.3 & 88.0 & 4.45 & 0.909\end{array}$

$\begin{array}{llll}40.7 & 46.7 & 3.16 & 1.470\end{array}$

$\begin{array}{llll}19.3 & 65.3 & 3.89 & 1.324\end{array}$

$\begin{array}{llll}40.7 & 35.3 & 2.84 & 1.087\end{array}$

$\begin{array}{llll}32.0 & 48.0 & 3.09 & 1.123\end{array}$

$\begin{array}{llll}32.7 & 55.3 & 3.23 & 1.216\end{array}$

$25.1 \quad 61.4 \quad 3.63$ $\begin{array}{llll}18.7 & 63.3 & 3.73 & 1.242\end{array}$

$\begin{array}{llll}40.0 & 42.0 & 2.99 & 1.170\end{array}$
If all statements of satisfaction are grouped according to the four areas of nursing care, the resulting data shows that slightly more than half of the respondents $(53.7 \%)$ are very pleased with the provided nursing care in the ICUs, around $47 \%$ are pleased with the nurses' rapport, $40 \%$ with postoperative care and $6 \%$ are satisfied with pain therapy (Figure 3).

When ranking dissatisfaction among the respondents from three different ICUs three main reasons are in the lead: information about the tolerance to pain and catheters $(40.7 \%)$ and ways of treating pain post-operationally (40\%). Almost a third of the respondents say they are dissatisfied with ineffectual treatments and therapies against pain. Thus, among the first five sources of dissatisfaction the problem of pain is represented four times. Roughly 30 percent of the respondents are not satisfied with the peace and quiet during their stay in the ICU and the amount of time devoted to discussing their medical condition. Approximately a fourth of them state being poorly informed about the course of postoperative care, not being satisfied by the rapport of the nurses and having problems with privacy during personal care. Slightly less than a fifth are dissatisfied with the availability of information about the length of the treatment, visiting hours and the attention paid by the nurses to their usual daily routines. Dissatisfaction with information available about the pa- 


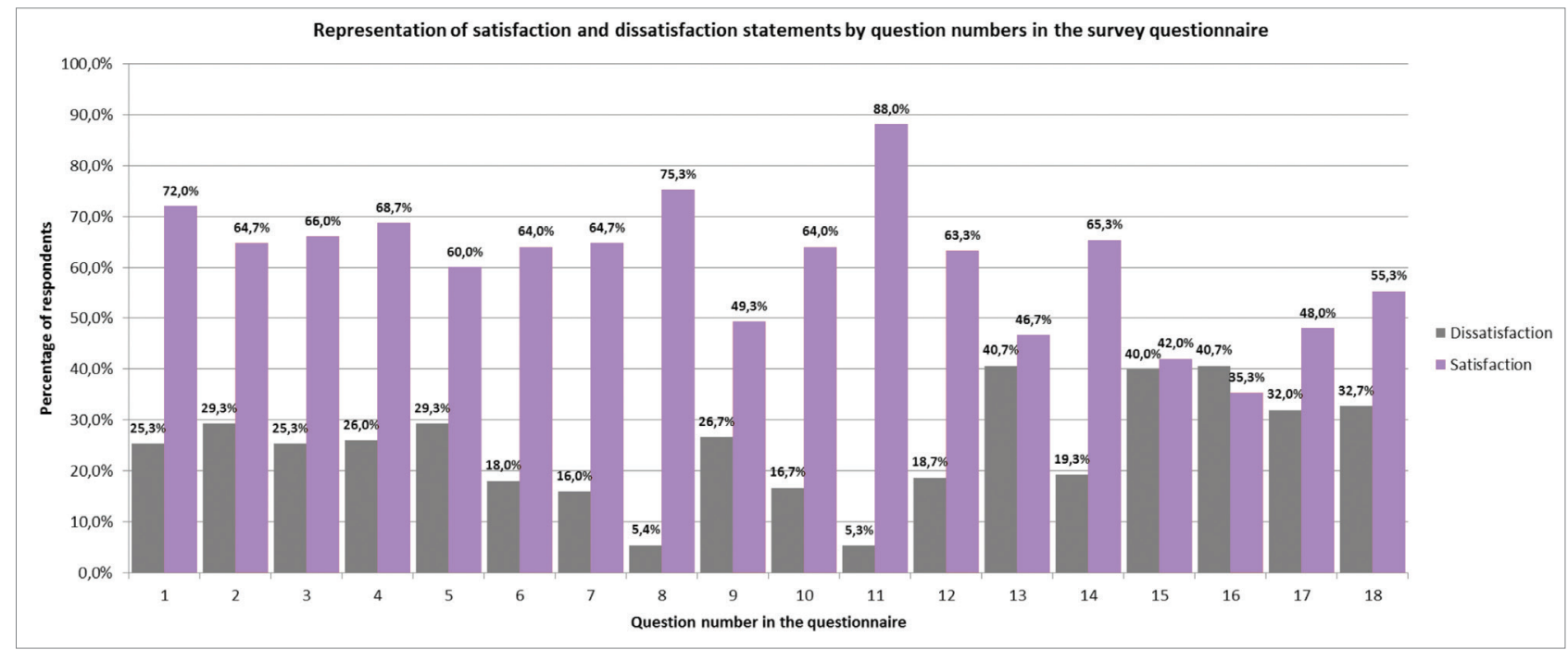

Figure 2. Representation of satisfaction and dissatisfaction statements by question numbers in the survey questionnaire

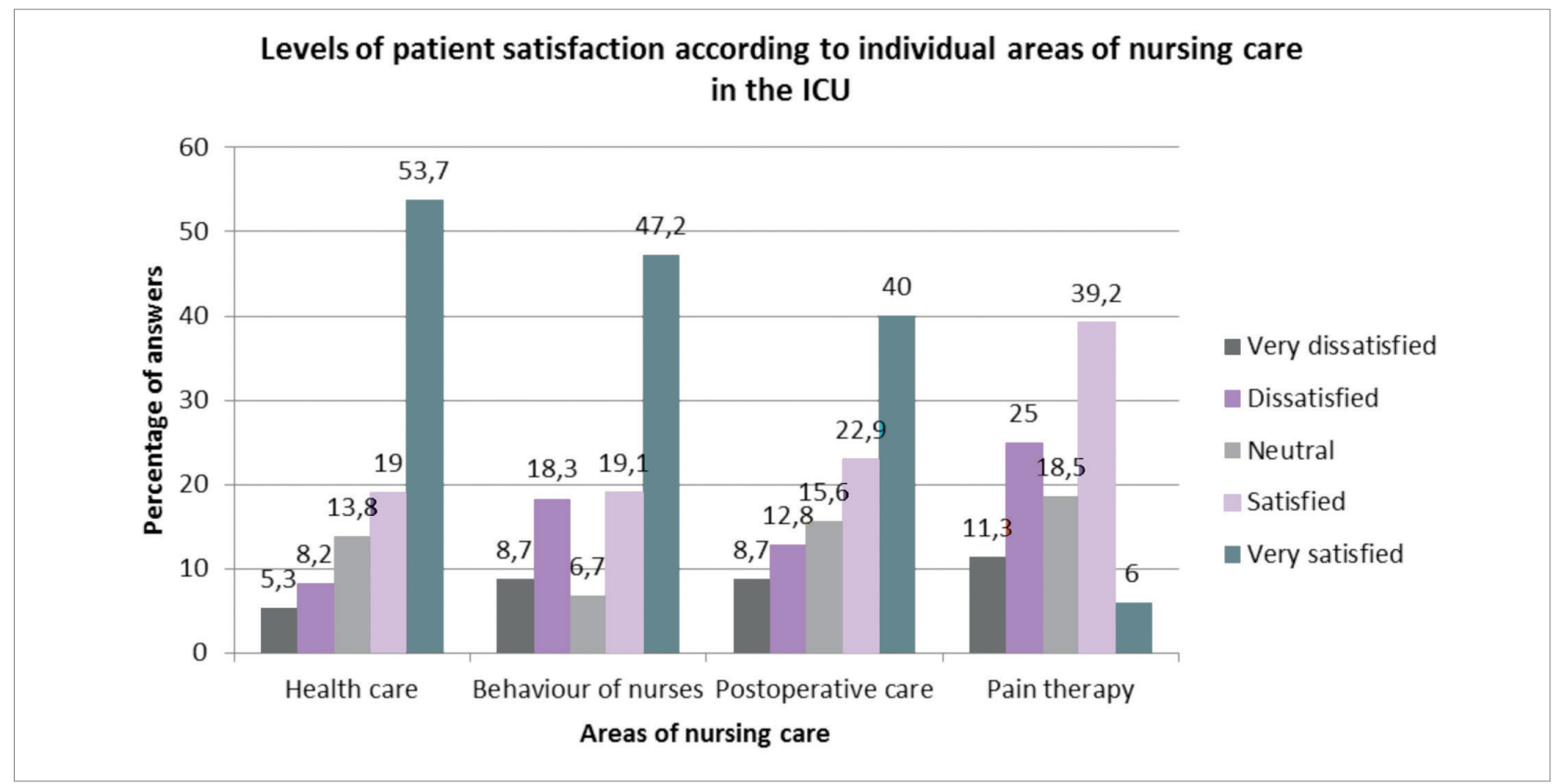

Figure 3. Levels of patient satisfaction according to individual areas of nursing care in the ICU

tient rights was expressed by $16.7 \%$ respondents, $16 \%$ expressed dissatisfaction with the attention devoted to their nutritional habits, whereas the least dissatisfaction was expressed with the possibility of practising ones religious needs (only 5\%) and the way their family has been informed about the condition of their health after the procedure (5\%). The processing of survey data with the aim of identifying the sources of patient dissatisfaction in the four areas of nursing care, taking into account all the questions (indicators) with regard to specific areas, showed that the respondents were mostly dissatisfied with pain therapies and treatments (34.6\%), the rapport of the nurses $(27.0 \%)$ and the amount of information available about postoperative care $(21.7 \%)$, whereas they were least dissatisfied regarding their inclusion in nursing care $(13.5 \%)$ (Figure 4). 


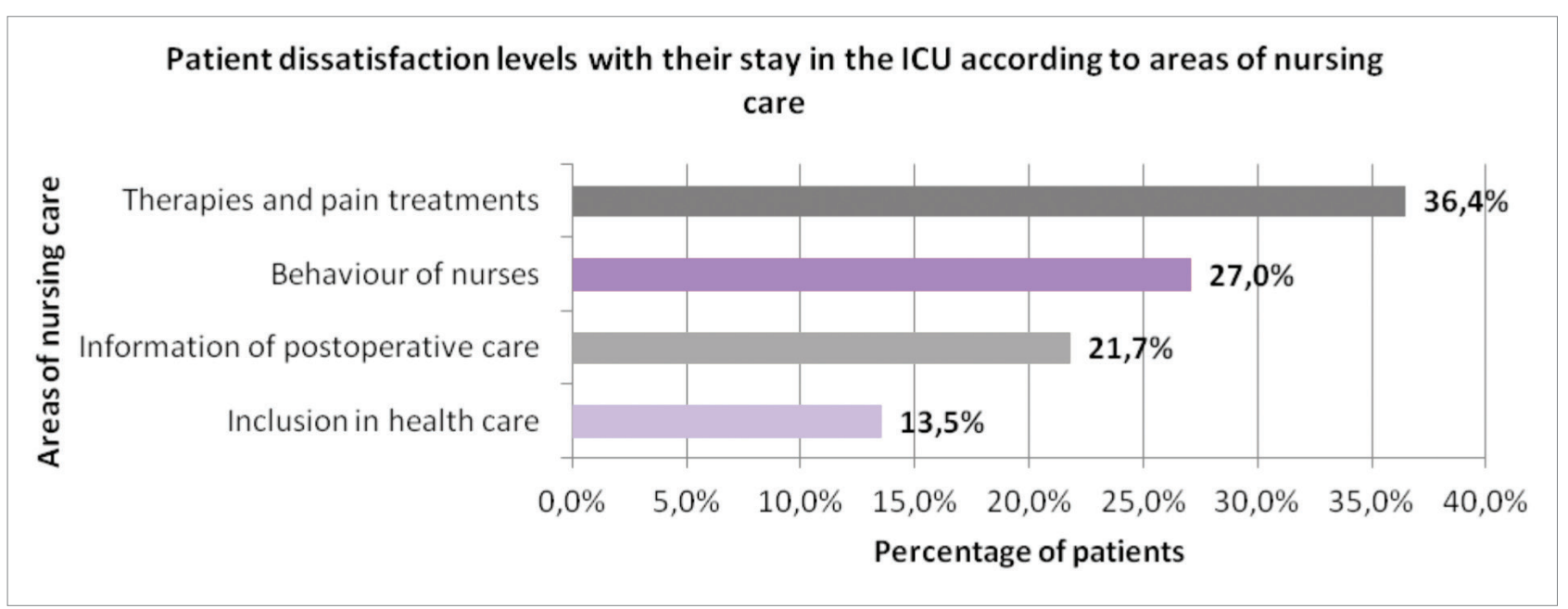

Figure 4. Patient dissatisfaction levels with their stay in the ICU according to areas of nursing care

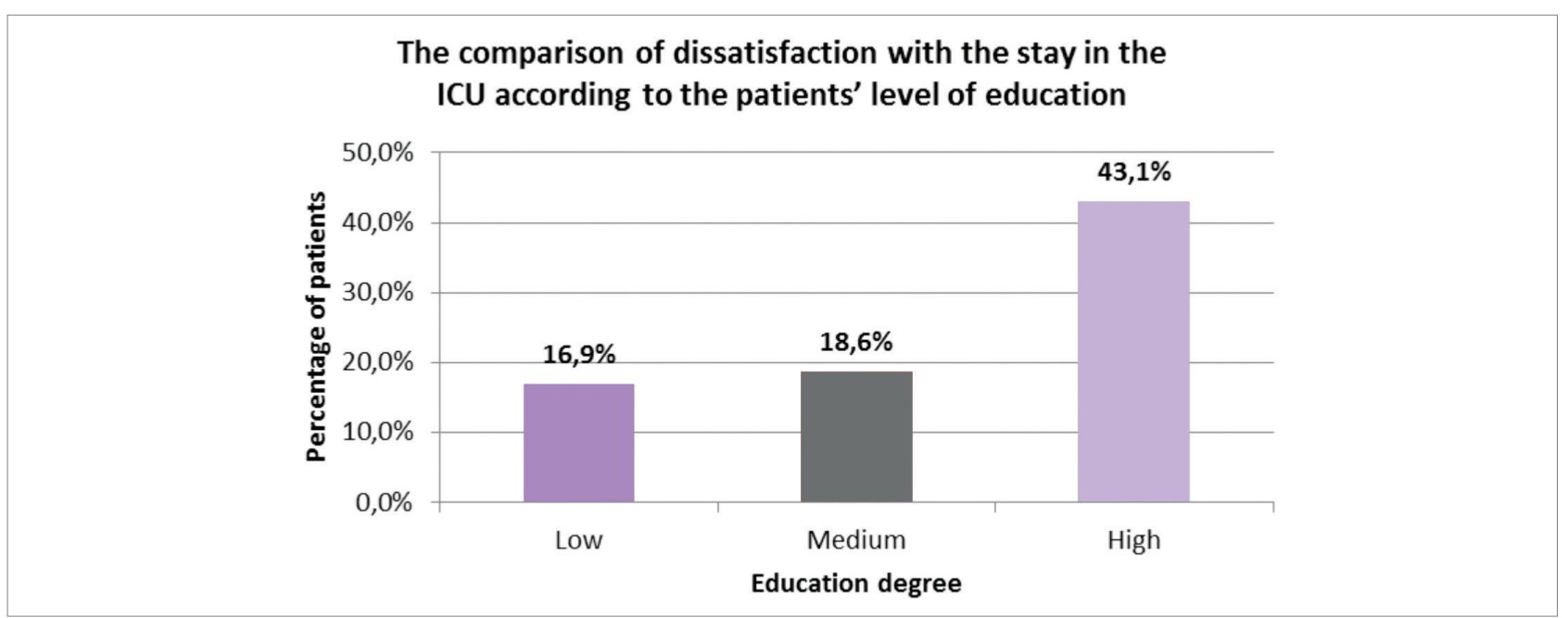

Figure 5. The comparison of dissatisfaction with the stay in the ICU according to the patients' level of education

Further data analysis shows statistically relevant differences in the perception of satisfaction or dissatisfaction among certain groups of patients (subpatterns of respondents). Dissatisfaction levels are expressed differently by patients in the three ICUs; there are differences between patients admitted for elective procedures and patients admitted through the emergency ward, as well as differences between patients who stayed more than five days and those who spent less time recovering post-operationally; at the same time, according to the demographic profile of the respondents, dissatisfaction grows proportionally to the level of education. Lowest levels of dissatisfaction were shown by respondents with primary education (16.9\%), followed by those with a secondary level of education (18.6\%), while patients with post-secondary vocational and tertiary education had much more complaints about the conditions of their stay in the ICUs and constituted a majority among those expressing dissatisfaction, with a proportion of $43.1 \%$ (Figures 5 and 6).

Patients with lower education are mostly dissatisfied with the availability of information on postoperative pain treatment $(54.5 \%)$ as well as the fact that they were not asked about their tolerance to pain (36.4\%). About $23 \%$ are not satisfied with the visiting hours and the amount of time devoted to them by the nurses.

Other complaints about the work of the nurses were poorly represented, in other words, the vast majority of patients with a lower level of education were on the whole satisfied with the nurses' rapport with the 


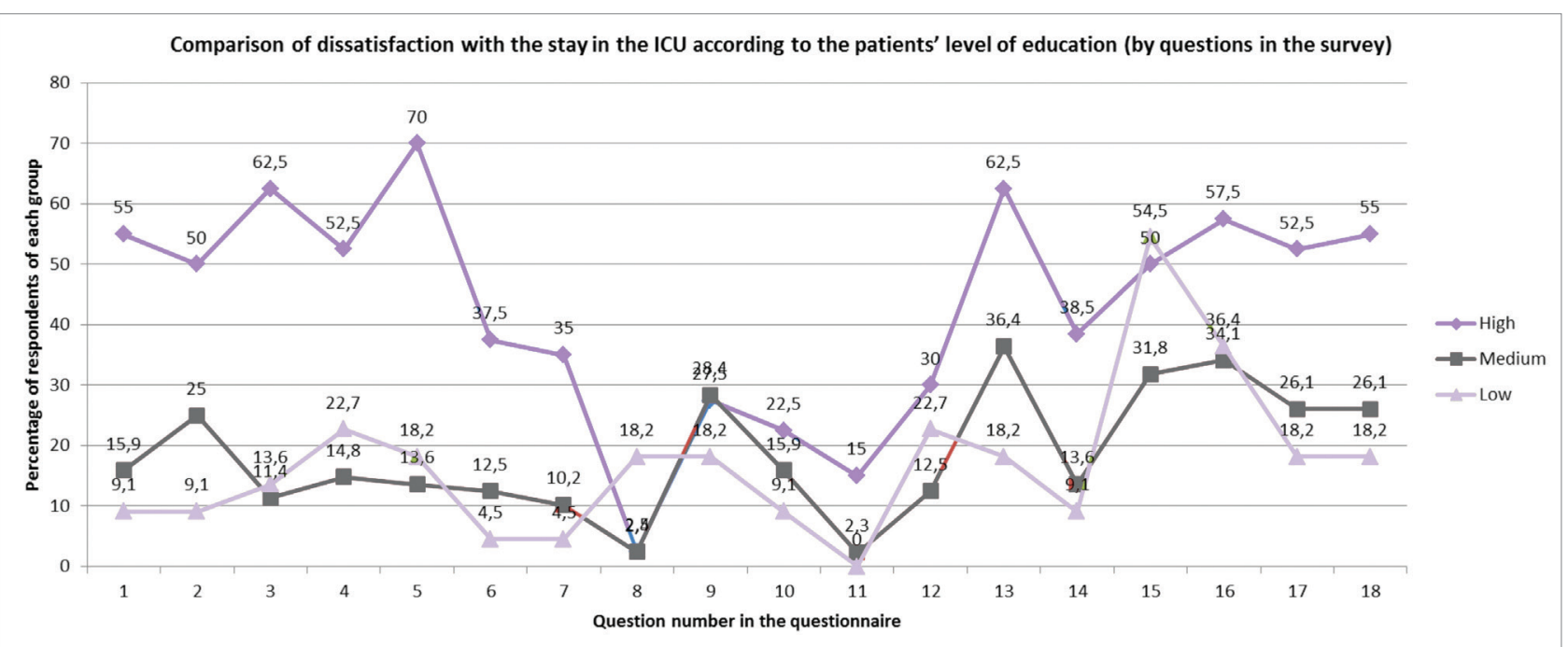

Figure 6. Comparison of dissatisfaction with the stay in the ICU according to the patients" level of education (by questions in the survey)

patients. It should be pointed out that patients with a low level of education did not protest about the way their families were informed about the condition of their health and visiting hours and that just $4.5 \%$ complained about nutrition or the attention paid by the nurses to their usual daily routines. What is interesting to mention is the dissatisfaction with the possibility of practising religious needs ranked in the middle $(18.2 \%)$, whereas for respondents with secondary education this reason is in the penultimate place (17th place), and in the last place among patients with post-secondary vocational and tertiary education. For patients with secondary education the reason number one on the dissatisfaction list is poor level of information about central venous catheters $(36.4 \%)$, followed by, as in those with a lower level of education, nurses failing to inquire about tolerance to pain (34.1\%). Less than a third (31.8\%) are not satisfied with the information about postoperative pain treatment $(31.8 \%)$, whereas $28.4 \%$ are dissatisfied with the course of postoperative care as such. The first mention of dissatisfaction about the nurses' work among patients in this group is in the 8th place $(15.9 \%)$ and refers to the nurses' approach to the patients when starting their shift, followed by the dissatisfaction about the amount of time nurses spent on patient care in the $10^{\text {th }}$ place $(14.8 \%)$. Least dissatisfaction has been expressed with the way patients' families were informed about their condition and visiting hours (just 2.3\%) as well as the possibility to practice religious rituals (3.4\%). $70 \%$ of patients with post-secondary vocational and tertiary levels of education were dissatisfied with the peace and quiet during their stay in the ICUs; $62.5 \%$ were dissatisfied with ensuring privacy during personal care and the availability of information about catheters; $57.5 \%$ criticized insufficient inquiries about their tolerance to pain, while $55 \%$ were dissatisfied with pain treatment and the nurses' rapport. As mentioned earlier, only $2.5 \%$ of respondents in this group were dissatisfied with the possibility to practice their religious needs. Dissatisfaction with information available to patients' families about the condition of their health is in the penultimate place of the dissatisfaction list for respondents with tertiary education, but it is mentioned by as much as $15 \%$ of respondents in this group. Dissatisfaction statements which have been grouped according to the areas of nursing care clearly show that the levels of dissatisfaction among patients with tertiary education is much higher than in other groups and that they were mostly dissatisfied with the nurses' rapport (58\%) and pain relief therapy (53.8\%) (Figure 7).

This study tried to confirm the hypothesis that the level of satisfaction with the provided nursing care is significantly lower among patients with a higher level of education, i.e. that the dissatisfaction level grows proportionally to the patient's level of education. Since a chi-squared with two degrees of freedom ( $d f=2 ; P=0.002)$ above the critical value has been obtained, the hypothesis can be accepted. The study also tried to confirm that patients will show a 


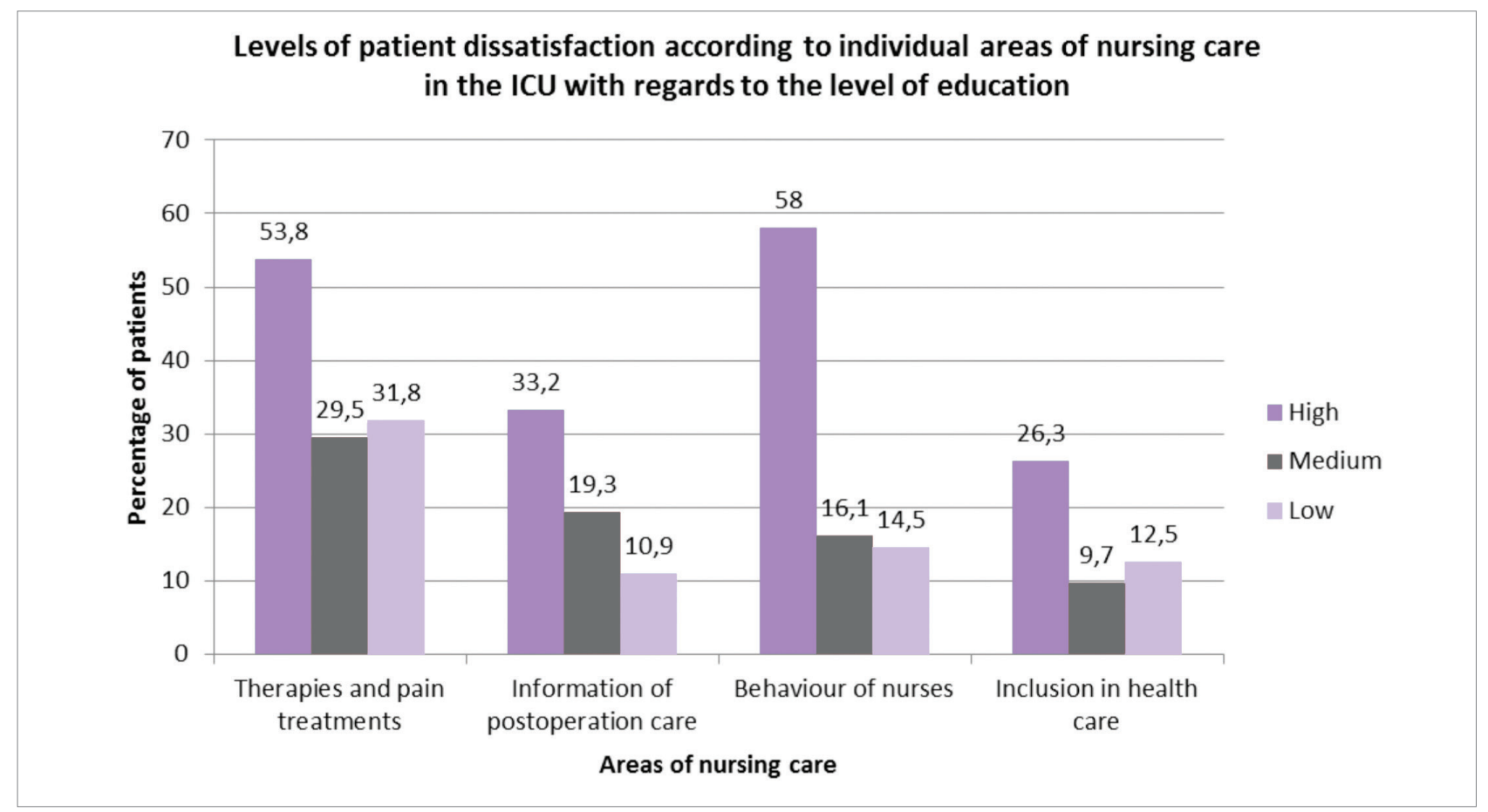

Figure 7. Levels of patient dissatisfaction according to individual areas of nursing care in the ICU with regard to the level of education

higher level of satisfaction with the provided nursing care when the length of their stay in the ICU is shorter. A normal stay in the ICU is for the purpose of this study defined as being no more than five days long. Namely, the longer patients stay in hospital wards, the higher the probability of finding potential reasons for dissatisfaction. However, a larger ratio was expected than the ratio of 65.2:52.8 in favour of the satisfied patients who spent up to 5 days in the ICUs as opposed to those who stayed for more than 5 days (Figure 8 ). We also tried to prove that the level of satisfaction is affected by the length of

\section{The comparison of overall satisfaction levels among patients with regards to the length of their stay in the \\ ICU}

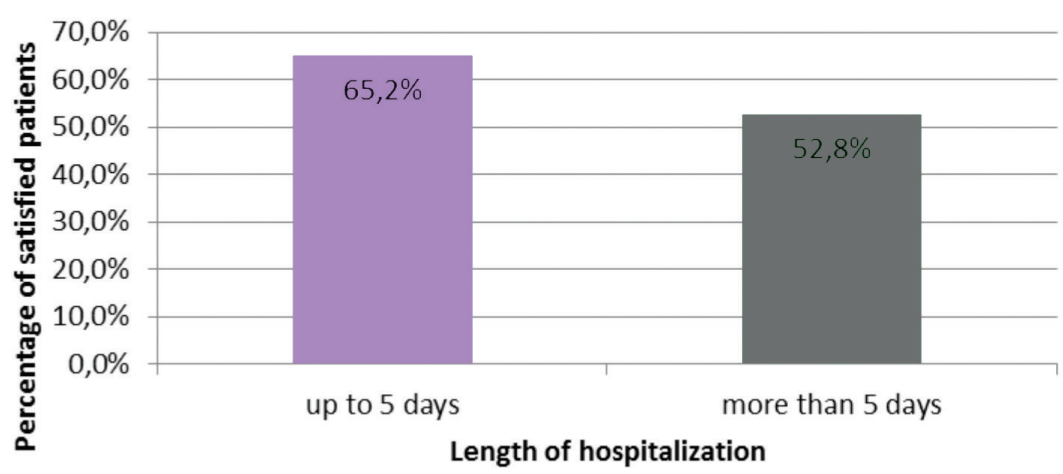

Figure 8. The comparison of overall satisfaction levels among patients with regard to the length of their stay in the ICU 
stay through statistical hypothesis testing. The second hypothesis that needed to be confirmed or dismissed, stated that patients will show a higher level of satisfaction with the provided nursing care when the length of their stay in the ICU is shorter. The hypothesis has been tested using the chi-squared test. The resulting values suggest that the hypothesis should be dismissed because the value of the chisquared test was lower than the critical value.

\section{Discussion}

Through the analysis of quality indicators for nursing care we acquired results on the basis of which changes could be implemented and the quality of nursing care improved. Since expert supervision based on the implementation of professional standards is one of the most widespread systems for the evaluation of the quality of professional work, these standards can be used to create work standards applicable to workplaces in Croatia. The measurement and comparison of processes and aims with the clinical indicators fits the concept of quality assurance and is the starting point for nursing care quality management. The results, obtained with the goal of identifying the sources of patient dissatisfaction in four areas of nursing care, taking into account all the questions with regard to specific areas, showed that the patients who participated in the study were mostly dissatisfied with pain therapies and treatments (34.6\%), the rapport of the nurses (27.0\%) and the amount of available information on postoperative care (21.7\%), whereas they objected the least to their inclusion in nursing care $(13.5 \%)$. Based on the resulting data, it is evident that the largest percentage of dissatisfaction is linked to pain therapy, indicating a lack of developed pain treatment protocols, which should be a necessity in an ICU, i.e. the assessment and therapy of pain should be standardised procedures. The rapport of nurses with the patients holds the second place on the list of complaints, pointing to the need for an improvement in the way nurses relate to the patients. The obtained results oblige us to make better care plans and improve the provided nursing care. The last on the list of reasons for dissatisfaction is the availability of information on post- operative care which indicates a possible problem regarding the multidisciplinary approach to patient education in the preoperative period. In view of the results obtained by the comparison between levels of satisfaction for different levels of education, the somewhat expected nature of obtained data points to the fact that patients with a higher level of education were less satisfied than patients with a lower level of education. As it was already pointed out, the level of education is a common variable used to follow differences in opinions. It is also to be expected that patients with a lower level of education would avoid taking part in the study for fear of not understanding the questions, thus distorting the results to a large extent. After testing the hypothesis it was determined that that patients with a higher level of education were less satisfied than patients with a lower level, which confirmed the hypothesis. From a sociological point of view the obtained result was expected because patients with higher education have higher expectations from the medical staff. Higher expectations arise from being better informed about patients' rights and better knowledge of the medical issue at hand. Hypothesis 2 was based on the assumption that patients who stayed longer in the ICU would be less satisfied. The starting hypothesis, which assumed that patients with shorter hospital stays, defined in our survey as a stay of no more than five days, were more satisfied with conditions in the ICUs than those who stayed longer than five days, has been dismissed by the study results. As a rule, the longer patients stay in hospital wards, the higher the probability of finding potential reasons for dissatisfaction, but this study determined that there is no statistical significance in the level of satisfaction with regard to the length of stay in the ICU.

\section{Conclusion}

The aim of this study was to show the importance of ensuring, managing and improving quality in the process of nursing care for patients. Nurses as the most numerous group among healthcare professionals have the greatest responsibility for the provision of quality health care. Patient satisfaction as a quality indicator in the healthcare system is one of the 
most important quality indicators because it provides direct feedback.

Based on the obtained results we can conclude that activities regarding pain therapy are the largest source of patient dissatisfaction in all three ICUs. Pain as a vital parameter must be regularly controlled and patients must be given proper therapy. In our case, it is obvious that a standardization of pain treatment is necessary along with an implementation of protocols for the use of analgesics and alternative pain relief methods. To improve quality, a multidisciplinary approach and close cooperation between physicians, nurses, physiotherapists and other staff is needed. Other sources of dissatisfaction, like the lack of information about postoperative care and intravascular catheters, as well as the ones mentioned above, point to the need for more involvement by medical staff, particularly nurses and physicians, in the education and psychological preparation for surgical procedures as an indispensable part of nursing care. In this regard it would be beneficial to develop informative brochures where patients could find part of the information, but at the same time not to stop talking to the patient as a key part to successful preoperative preparation, designed to satisfy the needs of all patients regardless of their level of education. The patients' stay in the ICU should be as brief as possible to avoid situations of reduced levels of patient satisfaction with the treatment.

\section{References}

1. Crusch CA, Martin CM. Quality Improvement in Critical Care: Selection and Development of Quality Indicators. Canadian Respiratory Journal. 2016; doi:10.1155/2016/2516765

2. Levy MM; Dellinger RP, Townsendet et al. The Surviving Sepsis Camaign: results of an international guideline - based performance improvement program targeting severe sepsis. Critical Care Medicine. 2010;38(2):367-74.

3. Simms AD, Baxter PD, Cattle BA, Batlin PD, Wilson Jl, West RM, Gale CP. An assessment of complete measures of hospital performance and associated mortality for patients with acute myocardial infarction. Analysis of individual hospital performance and outcome for the National Institute for Cardiovascular Outcome Research (NICOR). Eur. Heart J. Acute
Cardiovasc. Care 2012;(1):9-18. doi:http://dx.doi. org/10.1177/2048872612469132.

4. Boyle DK, Jayawardhana A, Burman ME, Dunton NE, Staggs VS, Bergquist-Beringer S, Gajewski BJ. A pressure ulcer and fall rate quality composite index for acute care units: measure development study. International Journal of Nursing Studies. 2016;63:73-81. http://dx.doi.org/10.1016/j.jjnurstu.2016.08.020.

5. Lopes Silveira TV, do Prado Junior PP, Guerra Siman A, de Olivera Fani Armano M. The importance of using quality indicators in nursing care. Rev Gaúcha Enferm. 2015;36(2):82-8. http://dx.doi.org/10.1590/19831447.2015.02.47702.

6. Vituri DW; Matsuda LM. Validaçao de conteúdo de indicadores de qualidade para avaliaçao do cuidado de enfermagem. Rev Esc Enferm USP. 2009;43(2):429-37.

7. dos Santos Alves DF, de Brito Guirardello E. Nursing work environment, patient safety and quality of carein pediatric hospital. Rev Gaúcha Enferm. 2016;37(2):e58817. http://dx.doi.org/10.1590/1983-1447.2016.02.58817

8. Cho E, Sloane DM, Kim EY, Kim S, Choi M, Yoo IY, et al. Effects of nurse staffing, work environments, and education on patient mortality: an observational study. Int J Nurs Stud. 2015;52(2):535-42. doi: 10.1016/j. ijnurstu.2014.08.006.

9. Van Bogaert PV, Dilles T, Wouters K, Van Rompaey BV. Practice environment, work characteristics and levels of burnout as predictors of nurse reported job outcomes, quality of care and patient adverse events: a study across residential aged care services. Open J Nurs. 2014; 4(5):343-55. doi:10.4236/ojn.2014.45040.

10. irwan M, Matthews $A$, Scott PA. The impact of the work environment of nurses on patient safety outcomes: a multi-level modelling approach. Int J Nurs Stud. 2013;50(2):253-63. doi: 0.1016/j.jnurstu.2012.08.020.

11. Rochefort CM, Clarke SP. Nurses' work environments, care rationing, job outcomes, and quality of care on neonatal units. J Adv Nurs. 2010;66(10):2213-24. doi:10.1111/j.1365-2648.2010.05376.x.

12. Ausserhofer $D$, Schubert $M$, Desmedt $M$, Blegen $M A$, De Geest S, Schwendimann R. The association of patient safety climate and nurse-related organizational factors with selected patient outcomes: a cross-sectional survey. Int J Nurs Stud. 2013;50(2):240-52. doi: 10.1016/j.ijnurstu.2012.04.007.

13. Aiken LH, Sermeus W, Van den Heede K, Sloane DM, Busse $R$, McKee $M$, et al. Patient safety, satisfaction, and quality of hospital care: cross sectional surveys of nurses and patients in 12 countries in Europe and the United States. BMJ. 2012;344:e1717. doi: 10.1136/bmj.e1717.

14. Aiken LH, Clarke SP, Cheung RB, Sloane DM, Silber JH. Educational levels of hospital nurses and surgical patient mortality. JAMA [Internet]. 2003;290(12):1617-23.

15. Schandl A, Falk AC, Frank C. Patient participation in the intensive care unit. Intensive Crit Care Nurs. 2017;42:105-109 
16. Camuci MB, Martins JT, Cardeli AAM, Robazzi MLCC. Nursing Activities Score: carga de trabalho de enfermagem em Unidade de Terapia Intensiva de queimados. Rev Latino-Am Enfermagem. 2014;69(4):638-43.

17. Magalhaes AMM, Dall-Agnol CM, Marck PB. Nursing workload and patient safety: a mixed method study with an ecological restorative approach. Rev LatinoAm Enfermagem. 2013;21:146-54.

18. Aiken LH, Cimiotti JP, Sloane DM, Smith HL, Flynn L, Neff DF. The effects of nurse staffing and nurse education on patient deaths in hospitals with different nurse work environments. Med care. 2011;49(12):1047-53.

19. Goncalves LA, Andolhe R, Oliveira EM, Barbosa RL, Faro ACM, Gallotti RMD, et al. Nursing allocation and adverse events/incidents in intensive care units. Rev Esc Enferm. 2012;48:71-7.
20. Quadros DV, Magalhaes AMM, Mantovani VM, Rosa DS, Echer IC. Analysis of managerial and healthcare indicators after nursing personnel upsizing. Rev Bras Enferm. 2016;69(4):638-43. DOI: http://dx.doi. org/10.1590/0034-7167.2016690410i.

21. Felli VEA. Condicoes de trabalho de enfermagem e adoecimento: motivos para a reducao da jornada de trabalho para 30 horas. Enferm Foco. 2012;3(4):178-81.

22. Kennedy GD, Tevis SE, Kent CK. Is There a relationship Patient Satisfaction and Favorable Outcomes. Ann Surg. 2014;260(4):592-600. doi:10.1097/ SLA.0000000000000932 


\section{ANNEX}

\section{PATIENT SATISFACTION AS A NURSING CARE QUALITY INDICATOR}

Thank you for taking part and filling out this questionnaire. It takes about 10 minutes to fill out the questionnaire.

Answer the questions by circling a number between 1 and 5, where 1 represents the lowest level of satisfaction, and 5 represents the highest level of satisfaction.

\section{GENERAL DATA}

AGE: $\quad 25-35 \quad 35-45 \quad 45-55 \quad 55-65 \quad 25$

SEX: $\quad M \quad F$

EDUCATION: Primary Secondary Tertiary Post-secondary vocational

SURGICAL PROCEDURE: cardiac surgery general surgery urological surgery

LENGTH OF STAY IN THE ICU: $\quad$ Up to 5 days 5 to 10 days $\quad$ More than 10 days

ADMISSION: $\quad$ elective emergency

\section{QUESTIONNAIRE}

1. Are you satisfied with the nurses' approach upon taking over their shift?

$\begin{array}{lllll}1 & 2 & 3 & 4 & 5\end{array}$

2. Are you satisfied with the time nurses spent talking with you?

$\begin{array}{lllll}1 & 2 & 3 & 4 & 5\end{array}$

3. Are you satisfied with the level of privacy during personal care?

$\begin{array}{lllll}1 & 2 & 3 & 4 & 5\end{array}$

4. Are you satisfied with the time the nurse spends on your care during their shift?

$\begin{array}{lllll}1 & 2 & 3 & 4 & 5\end{array}$

5. Are you satisfied with the peace and quiet during your stay in the ICU?

$\begin{array}{lllll}1 & 2 & 3 & 4 & 5\end{array}$

6. Are you satisfied with how the nurse is paying attention to your usual routines?

$\begin{array}{lllll}1 & 2 & 3 & 4 & 5\end{array}$

7. Are you satisfied with the attention paid to your nutritional habits?

$\begin{array}{lllll}1 & 2 & 3 & 4 & 5\end{array}$

8. Are you satisfied with the possibility to practice your religious rituals?

$\begin{array}{lllll}1 & 2 & 3 & 4 & 5\end{array}$

9. Have you been informed about the course of postoperative care?

$\begin{array}{lllll}1 & 2 & 3 & 4 & 5\end{array}$

10. Have you been informed about your rights as a patient?

$\begin{array}{lllll}1 & 2 & 3 & 4 & 5\end{array}$

11. Are you satisfied with how your family was informed about your postoperative state and visiting hours?

$\begin{array}{lllll}1 & 2 & 3 & 4 & 5\end{array}$


12. Are you satisfied with the visiting hours during your stay at the ICU?

$\begin{array}{lllll}1 & 2 & 3 & 4 & 5\end{array}$

13. Are you satisfied with the information provided about catheters that were placed because of the surgical procedure? $\begin{array}{lllll}1 & 2 & 3 & 4 & 5\end{array}$

14. Have you been informed about the average length of stay in the ICU?

$\begin{array}{lllll}1 & 2 & 3 & 4 & 5\end{array}$

15. Have you been informed about ways of pain treatment in postoperative care?

$\begin{array}{lllll}1 & 2 & 3 & 4 & 5\end{array}$

16. Were you asked questions about your tolerance to pain?

$\begin{array}{lllll}1 & 2 & 3 & 4 & 5\end{array}$

17. Did you get adequate pain treatment upon request?

$\begin{array}{lllll}1 & 2 & 3 & 4 & 5\end{array}$

18. Are you satisfied with the pain treatment in the ICU?

$\begin{array}{lllll}1 & 2 & 3 & 4 & 5\end{array}$




\section{ZADOVOLJSTVO PACIJENTA KAO INDIKATOR KVALITETE ZDRAVSTVENE NJEGE U JEDINICI INTENZIVNOG LIJEČENJA}

\section{Sažetak}

Cilj. Zadovoljstvo bolesnika pruženom zdravstvenom njegom jedan je od važnih indikatora kvalitete. Cilj istraživanja bio je utvrditi čimbenike i razinu zadovoljstva pacijenata u jedinici intenzivnog liječenja. Također, cilj je bio ustanoviti i usporediti razine zadovoljstva među pacijentima s obzirom na stupanj obrazovanja i duljinu boravka u jedinicama intenzivnog liječenja.

Hipoteze. 1. hipoteza. Razina zadovoljstva kvalitetom pružene zdravstvene njege kod pacijenata koji imaju viši stupanj obrazovanja znatno je niža. 2. hipoteza. Pacijenti pokazuju veću razinu zadovoljstva pruženom zdravstvenom njegom ako je vrijeme boravka u jedinici intenzivnog liječenja kraće.

Materijali i metode. Istraživanje je provedeno slučajnim odabirom 150 bolesnika koji su bili liječeni u jedinicama intenzivnog liječenja u Kliničkom bolničkom centru Zagreb u razdoblju od šest mjeseci. Anketni upitnik sadržavao je ukupno 24 pitanja zatvorenog tipa. Hipoteze istraživanja testirane su hi-kvadrat testom.

Rezultati. Istraživanjem je potvrđena početna 1. hipoteza da pacijenti s višim stupnjem obrazovanja imaju nižu razinu zadovoljstva nego pacijenti s nižom razinom obrazovanja. Druga je hipoteza, kojom je pretpostavljeno da su pacijenti s kraćim boravkom, koji je u našoj anketi definiran duljinom do maksimalno pet dana, zadovoljniji uvjetima na odjelima intenzivne skrbi od onih koji su zadržani dulje od pet dana, odbačena.
Zaključak. Kod pacijenata s višom razinom obrazovanja postavljaju se veća očekivanja od zdravstvenih djelatnika tako je da samim tim i razina zadovoljstva zdravstvenom njegom niža. Pretpostavka da duljim boravkom pacijenata na bolničkim odjelima raste i vjerojatnost pronalaženja eventualnih razloga nezadovoljstva nije statistički značajna pa ova varijabla nema značenje u procjeni zadovoljstva pacijenata.

Ključne riječi: indikatori kvalitete, zadovoljstvo bolesnika, medicinska sestra, zdravstvena njega 